\title{
Monitoring Coastline Changes Using Landsat Application in Batu Mejan Beach
}

\author{
Ni Nyoman Pujianikia,", Gusti Bagus Armana Santosa Widhi ${ }^{\text {a }, ~ I ~ N y o m a n ~ G d e ~ A n t a r a ~}{ }^{a}$, \\ I Gede Rai Maya Temaja ${ }^{\mathrm{a}}$, Takahiro Osawa ${ }^{\mathrm{b}}$ \\ ${ }^{a}$ Udayana University, Kampus Bukit Jimbaran, 80361, Bali, Indonesia \\ ${ }^{b}$ Yamaguchi University, Tokiwadai, 755-8611, Ube, Japan \\ E-mail: "pujianiki@civil.unud.ac.id
}

\begin{abstract}
Monitoring Coastline changes is a very important task to assess and evaluate the condition of the coastal area. Accurate results of changes in coastline are very useful as a consideration in making decisions for coastal area management and planning for future coastal development. Therefore, coastline changes, both erosion and accretion were examined in this study. Batu Mejan Beach is selected as a study area. It is a tourism destination often visited by foreign and local tourists in North Kuta Beach. Its current condition is very poor because of the erosion that has occurred. The government has tried to build a sea wall for protection, but the structure has failed. Remote sensing is a method that can monitor shoreline changes more efficiently than taking measurements directly into the field. With the remote sensing method, changes in the shoreline at a certain period can be investigated. The remote sensing analysis method is used to extract coastlines from Landsat 7 satellite images in 2002 and Landsat 8 in 2018. Landsat was analyzed using a combination approach of threshold and band ratio methods of infrared bands and green bands. Image processing uses ENVI 5.3 software and ArcGIS 10.4.1 with the Quoted Shoreline Analysis System (DSAS) extension to make transect shoreline calculations. The results of the analysis of the rate of change in the coastline along Batu Mejan Beach showed abrasion of 0.11-5.14 $\mathrm{m} / \mathrm{year}$ and accretion of $0.29-0.84 \mathrm{~m} / \mathrm{year}$.
\end{abstract}

Keywords-Coastline changes; Landsat; erosion; accretion.

Manuscript received 9 Sep. 2020; revised 12 Dec. 2020; accepted 24 Feb. 2021. Date of publication 30 Apr. 2021. IJASEIT is licensed under a Creative Commons Attribution-Share Alike 4.0 International License.

\section{INTRODUCTION}

Coastal areas have economic and ecological functions and roles that are very important so that the occurrence of damage in coastal areas can disrupt the activities and sustainability of development in the area [1]. Damage to this coastal region can be caused by two factors, namely natural factors and human intervention factors. Natural factors are factors that are caused naturally, such as wind, waves, and others. Whereas human intervention factors such as development activities, beach reclamation, coastal containment, and others. The coast is a land area on the seashore that is still under the influence of the sea, such as tides, sea breezes, and seawater seepage [2]. The process of beach formation is influenced by littoral transport, which is the motion of sediments in the nearshore area by waves and currents.

The coastline is the boundary between land and sea that changes dynamically because it is affected by sea-level fluctuations and sediment movement. Accretion can occur if sediment is deposited on the coastline, while erosion or abrasion occurs when landslides and sediment loss occur on the coastline. With regard to changes in the area of the region due to changes in coastline, the Regional Government, both Provincial and District/City, has the task of carrying out an inventory of changes in the area caused by nature, including delta and abrasion and by human activities [3]. Monitoring changes in the coastline is important for the protection of coastal areas and the development of sustainable coastal areas. From the monitoring results, a map of the coastal area can be made, and then it can be evaluated whether the area is prone to disaster or not.

Bali is one of the regions in Indonesia, which is known to have a very attractive charm from the potential of its beaches. Most of the beaches in Bali are used as tourist attractions, such as beaches in the Canggu area, North Kuta, Badung Regency. This area has beautiful beaches whose charm is widely known. One of the beaches is Batu Mejan beach 
which both local and foreign visitors visit. As a tourism area, tourists visit Batu Mejan Beach to do surfing, parasailing, and relaxing on beach chairs facing the sea to enjoy the sunset. Besides being a tourism area, Batu Mejan Beach, a sacred area, functions as a place to hold religious activities by local people, especially those who are Hindu. Batu Mejan Temple, located in the coastal area of Batu Mejan Beach, is a temple sanctified by Hindus in Bali as a place of worship. Based on the Badung Regency Regulation Number 26 of 2013 concerning the Spatial Planning of the Badung Regency in 2013-2033, the Batu Mejan Beach area is included in the coastal abrasion prone area, which includes the southern coastal area of Badung Regency [4].

However, Bali's regency, including the Badung regency, now faces a great challenge to safeguard coastal and coastal areas from the threat of increasing erosion rates. A survey conducted by the Ministry of Public Works showed a reduction in Bali coastal areas by $30 \%$ due to environmental degradation and sea erosion. From data released by the Bali Environment Agency, 48 beaches in Bali have experienced acute erosion; in the last ten years, $181.7 \mathrm{~km}$ of coastal land has been lost, and this is about $41.5 \%$ of the total length of the coastline in Bali. Based on the last evaluation results conducted by the Bali Penida River Basin Agency in 2015 [5], the beach in the Badung Regency region that experienced abrasion was $83.8 \mathrm{~km}$ long and erosion along $23.4 \mathrm{~km}$. In 2017, many damaged and broken beaches were found at a number of abrasion-affected shores in the Canggu area, including to the west and east of Batu Mejan Temple. Several studies to reduce Batu Mejan Beach's erosion had carried out by [6] and [7]. Given the importance of the Batu Mejan beach function as a tourism area and place for religious ceremonies and the importance of the existence of the Batu Mejan Temple located on the coast, it is necessary to monitor the condition of the coastline. One technique that is considered effective to be applied in coastline monitoring is a remote sensing method.

Remote sensing is a useful tool for detecting coastline change. It plays an important role in spatial data acquisition from an economic perspective. Digital spatial data analysis and mapping, remote sensing, and GIS are widely applied in environmental and natural resources monitoring. Several studies in coastline detection, extraction, and monitoring using satellite imagery have been carried out to find out that this technique is an efficient technique [8]-[10]. The results of their analysis showed that erosion and accretion had occurred along the coastline.

Digital Shoreline Analysis System (DSAS) is additional software that works on ArcGIS software developed by ESRI and USGS. The Digital Shoreline Analysis System is used to calculate changes in coastline position based on statistical and geospatial based time. DSAS uses a point as a measurement reference, where points are generated from intersections between the user-made transect lines and timebased coastlines [11]. DSAS has been proven that can be used as useful tools to extract coastline changes [12]-[15].

Landsat satellite imagery has several advantages, including being able to record a fairly narrow area with a resolution of $30 \times 30$ meters, references to processing Landsat images are found, proven to be able to analyze the coastline [10][16]-[18], and can be downloaded for free. An analysis of shoreline changes in Batu Mejan coastline was done using DSAS software, whose satellite image data was captured using the Landsat satellite in this study. The results of this monitoring are expected to be useful both in mitigating and rehabilitating erosion impacts in the Batu Mejan Beach.

\section{MATERIAL AND METHOD}

The method used in this research is qualitative research by applying survey methods, including interviewing with local people, environmental observations, documentation, field measurements and literature studies. The research was conducted from February 2019 to July 2019 with case studies along Batu Mejan Beach, Canggu Village, Kuta Utara District, Badung Regency, Bali Province can be seen in Figure 1.

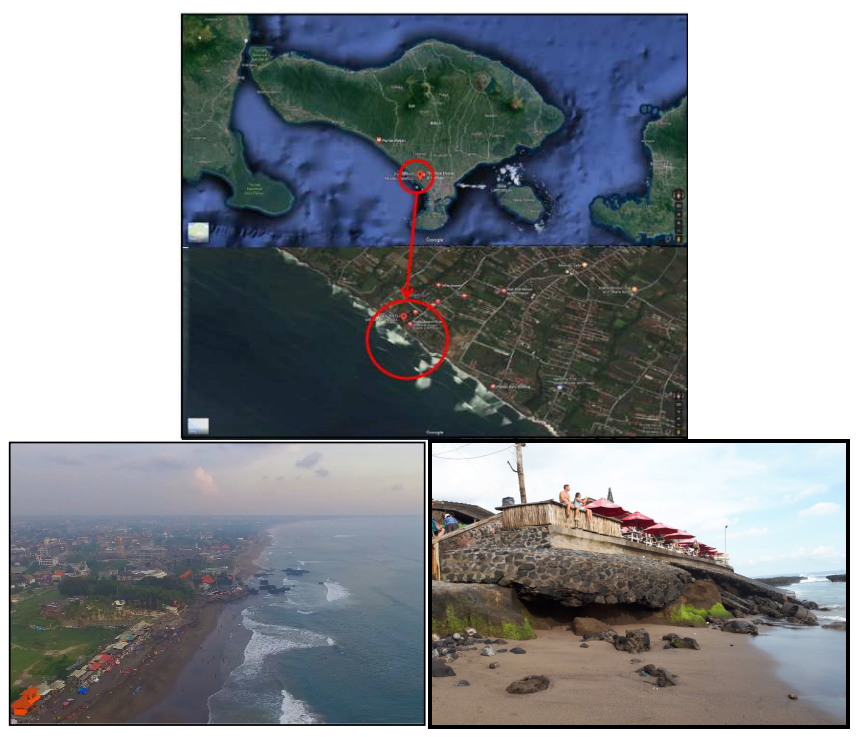

Fig. 1 Location of study.

Figure 1 showed the shoreline when the study was conducted, which was taken using aerial photographs. In some parts of the sea wall has been damaged by the waves. Information from local peoples was obtained that the coastline at the location had declined from the previous year.

Landsat satellite imagery has been widely used to analyze changes in coastlines. Satellite imagery data is taken from certain images at certain times to be compared. The time period and resolution to be used to determine the type of image to be used. The result of this overlay is the final result of making a map of changes in the coastline of the area to be studied. Changes in the coastline consist of accretion areas and erosion areas. Based on the changes that can be determined, the limits of change and, at the same time, the area that is the final result of the study. In this study, shoreline changes were investigated at the study sites in 2002 and 2018. This is an advantage of Landsat imagery which has data in 2002. Images in 2002 were taken using Landsat 7, while images in 2018 were taken using Landsat 8. Landsat image processing uses the threshold value approach and the band ratio. Image processing results with threshold suppressors and band ratios will be in the form of binary with the aim of making it easier to do classification in shoreline extracts. The coastline along the North Kuta Sub- 
district that was used as the object of research based on field surveys has fine black sand, gently sloping morphology.

Process and correction of satellite image data consist of radiometric correction, cutting of satellite imagery area, orthorectification correction, a combination of satellite image bands, vector digitization, coastline correction, and verification of image results.

\section{RESULT AND DISCUSSION}

The image processing results include Landsat threshold results, band ratio, threshold and band ratio combination, classification, and shoreline vector.

\section{A. Image Cutting}

Image cutting is done to determine the research area because not all areas in the image will be processed. At the stage of the image, cutting is done using the Region of Interest method; in that way, the image is cut to the boundary of a region in the form of a vector. The boundary used in this study is the boundary of the North Kuta District, with coordinates $8.644840^{\circ} \mathrm{S} 115.163254^{\circ} \mathrm{E}$. Cutting results can be seen in Figure 2.

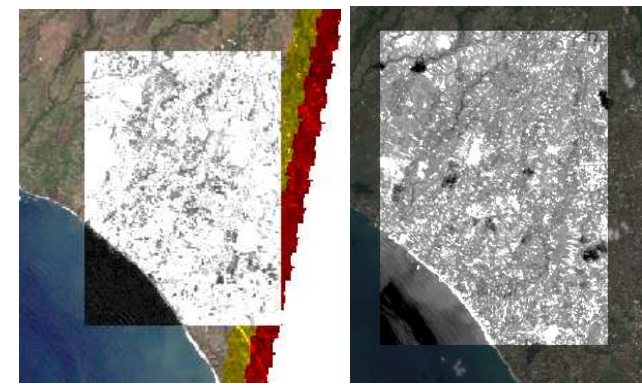

Fig. 2 Image Cutting Result in 2002 and 2018

\section{B. Geometric Correction}

Geometric corrections are made to ensure that both satellite data have the same geographical information because an overlay process will be carried out. One important parameter is the similarity of spatial resolution; in this case, both satellite data have the same spatial resolution, which is $30 \times 30$ meters. The geometric correction process was carried out on the image in 2002, referring to the 2018 image, which has been corrected. Geometric correction produces an error value called RMSE, where the RMSE value cannot be more than 1 .

\section{Radiometric Correction}

Radiometric correction is the process of merging and uniforming the colors of several images into one unit, both digitally and visually, by eliminating the fuzziness that occurs in image data.

\section{Composite Band}

The satellite imagery used is Landsat satellite imagery which is multitemporal with a medium spatial resolution of 30x30 meters. The use of medium resolution satellite imagery is suitable for spatial monitoring of coastline dynamics. RGB composite display on Landsat imagery can interpret water, coast (coastline), vegetation, and settlement. The 2002 composite band results can be seen in Figure 3, and composite band results for Landsat 8 can be seen in Figure 4.

\section{E. Image Thresholding}

The image threshold value of the infrared sensor has an output in the form of a binary image. This approach considers the reflectance value reflected by objects on the earth after receiving waves from satellites. In this approach, the reflectance value of land has an extremely high value, while it has zero value for the sea. The separation of land and sea is converted into binary imagery to facilitate nonguided classification (unsupervised classification). The results of the classification of the threshold value are shown in Figure 5.

\section{F. Band Ratio}

The band ratio produces binary images, which are a combination of bands 4,5 , and 2 on Landsat 7 and a combination of bands 5, 6, 3 on Landsat 8 . This band ratio approach is to cover the weakness of the threshold that is not classifying vegetation and sand on the beach. The results of the $4 / 2$ band ratio and the binary image of Landsat 7 are shown in Figure 7. Meanwhile, the results of the band ratio of 5/3 and the binary image of Landsat 8 are shown in Figure 8 . The results of the $5 / 2$ band ratio and the binary image of Landsat 7 are shown in Figure 9. The band ratio 6/3 and the binary image of Landsat 8 are shown in Figure 10.

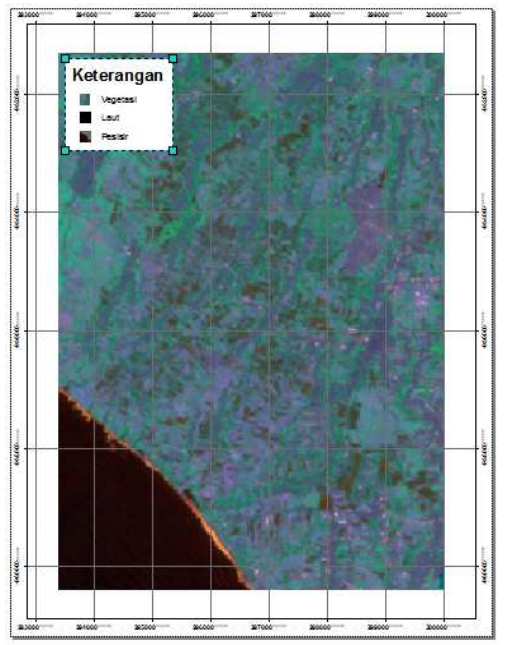

Fig. 3 Composite Band of 2002

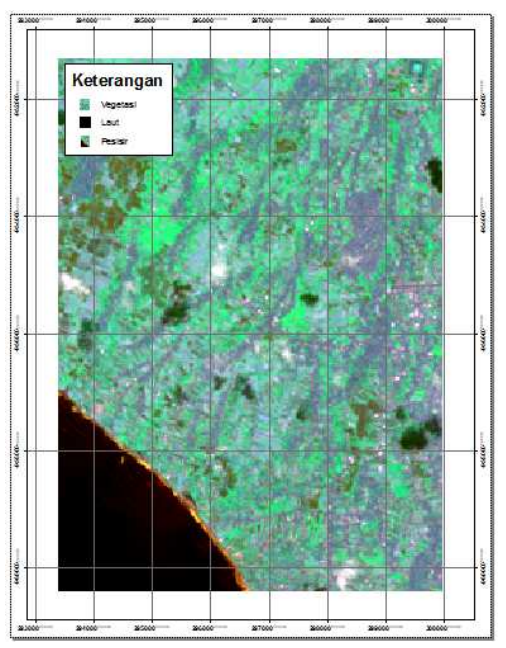

Fig. 4 Composite Band of 2018 


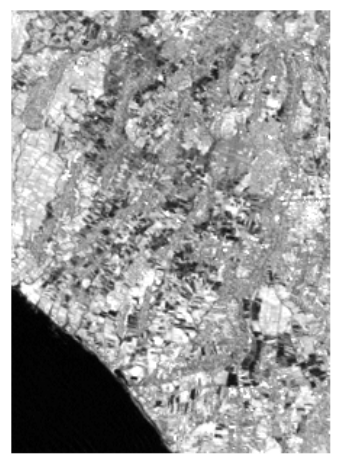

a

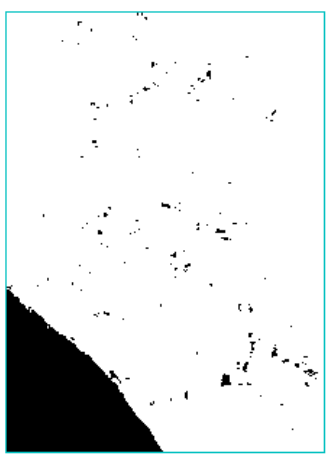

b
Fig. 5 Landsat 7 image before masking (a) and after masking (b) with threshold suppressors in band 5

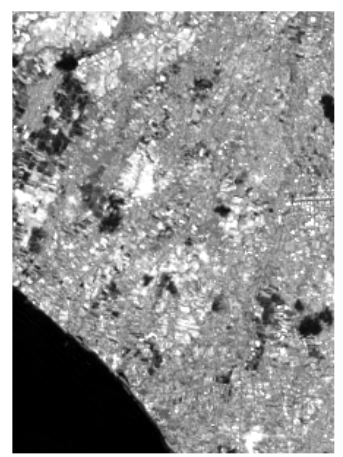

a

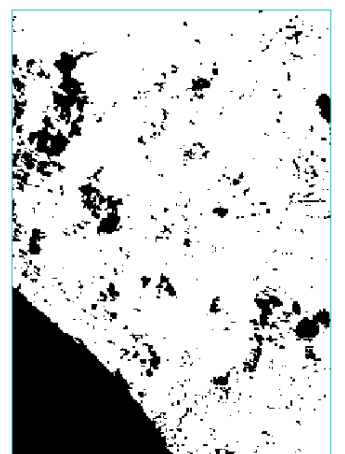

b
Fig. 6 Landsat 8 image before masking (a) and after masking (b) with threshold suppressors in band 6

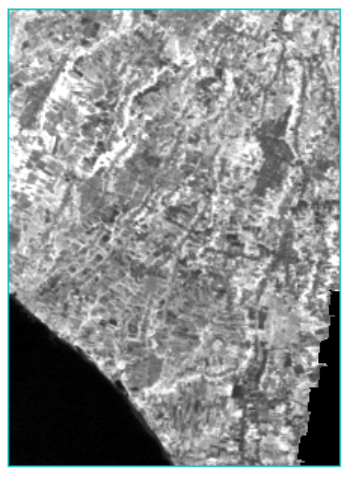

a

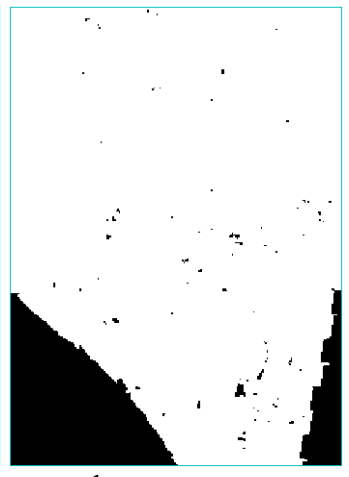

b
Fig. 7 Landsat 7 image results from the band ratio 4/2 (a) and after masking (b)

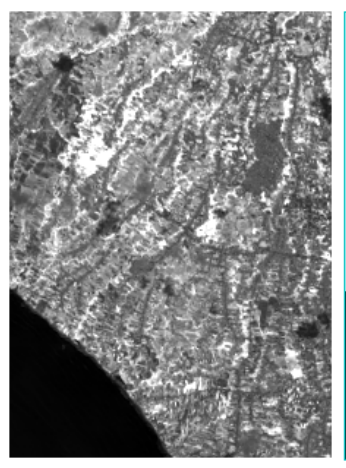

a

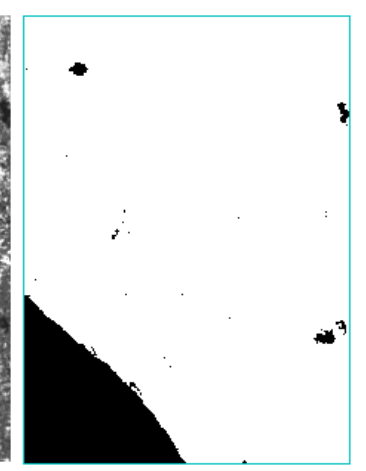

b
Fig. 8 Landsat 8 image results from the band ratio $5 / 3$ (a) and after masking (b)

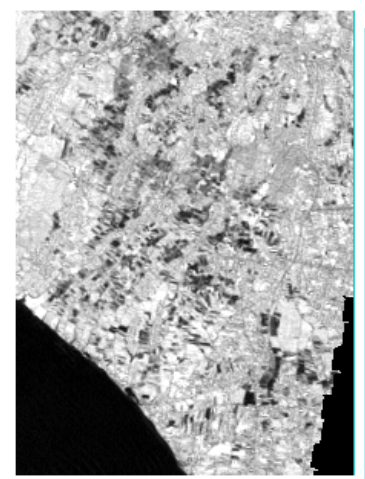

a

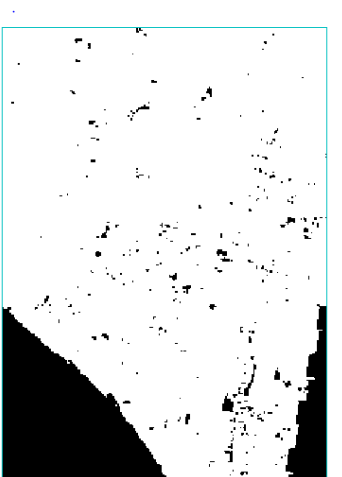

b
Fig. 9 Landsat 7 image results from band ratio 5/2 (a) and after masking (b)

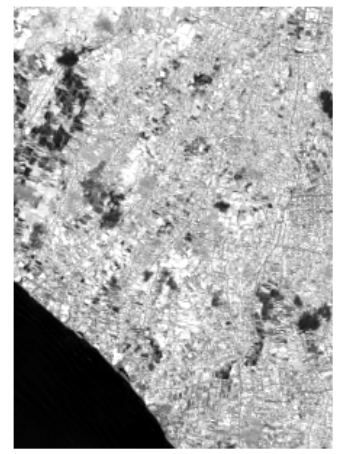

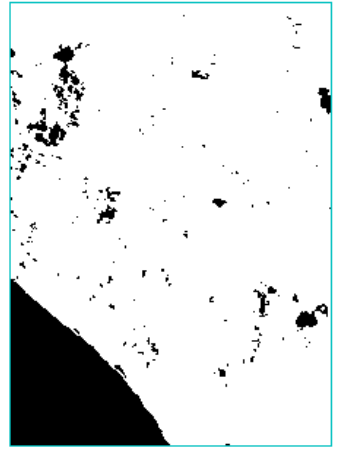

b
Fig. 10 Landsat 8 image results from band ratio $6 / 3$ (a) and after masking (b)

\section{G. Combination of Threshold with Band Ratio}

The result of each Landsat image threshold and band ratio approaches, then combine with the multiplication operation to get the binary image of the two approaches. The shoreline delineation results from Landsat imagery are more accurate by combining the threshold and band ratio approaches. The merging of the threshold with the band ratio is done by multiplication. The combined results of the band ratio with the threshold can be seen in Figure 11.

\section{H. Classification and Digitization of Coastline Vectors}

Binary imagery resulting from the combined threshold and band ratio is classified between sea and land. The classification used is the supervised classification. The results of this classification are vectors which are conversions of raster with polygon format shapefiles.

The steps taken after all the correction processes to the separation of land and sea boundaries from the Landsat satellite imagery for the North Kuta area are the digitization process. In this process, the corrected image in vector form is used as a drawing base for the shoreline to be analyzed. The results of the vector that have been corrected can be seen in Figure 12 for 2002 and Figure 13 for 2018.

The vector of the results already shows the difference, which one island and the other is the ocean. The vector results that have been obtained are used as a basis for digitizing the coastline, which is continued using the ArcGIS program. The results of digitization can be seen in Figure 14. 


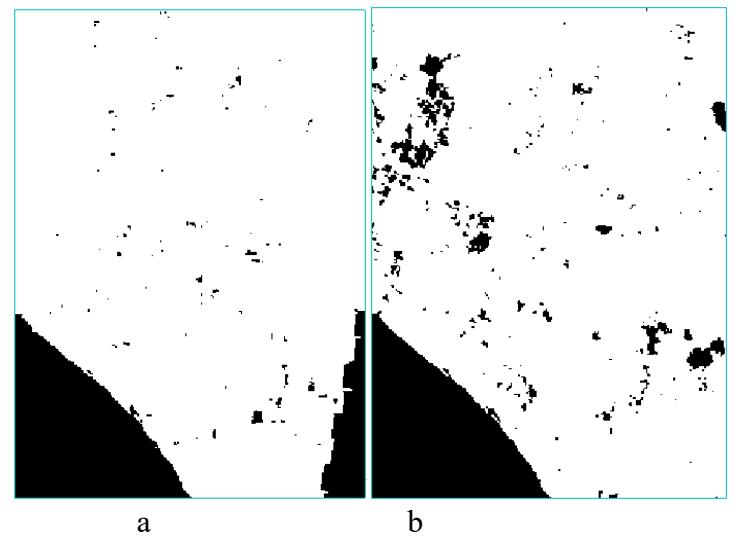

Fig. 11 The combination of 2002 (a) and the combination of 2018 (b)

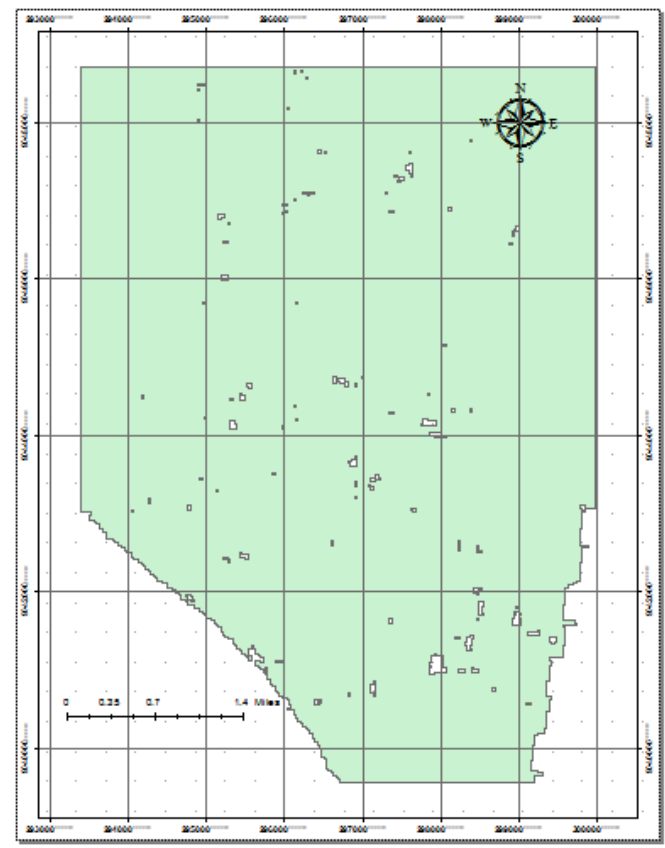

Fig. 12 Vector of coastline polygon in 2002

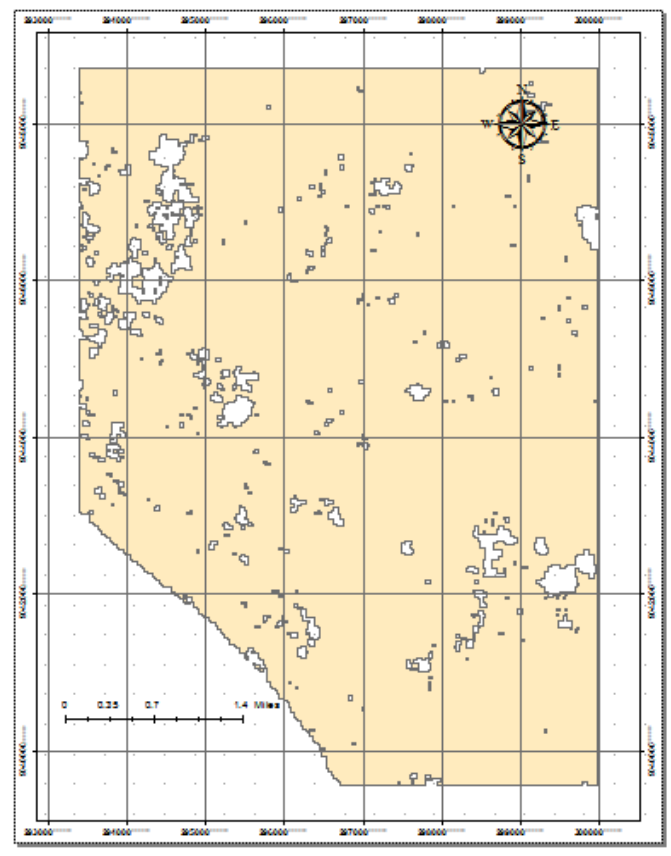

Fig. 13 Vector of coastline polygon in 2018

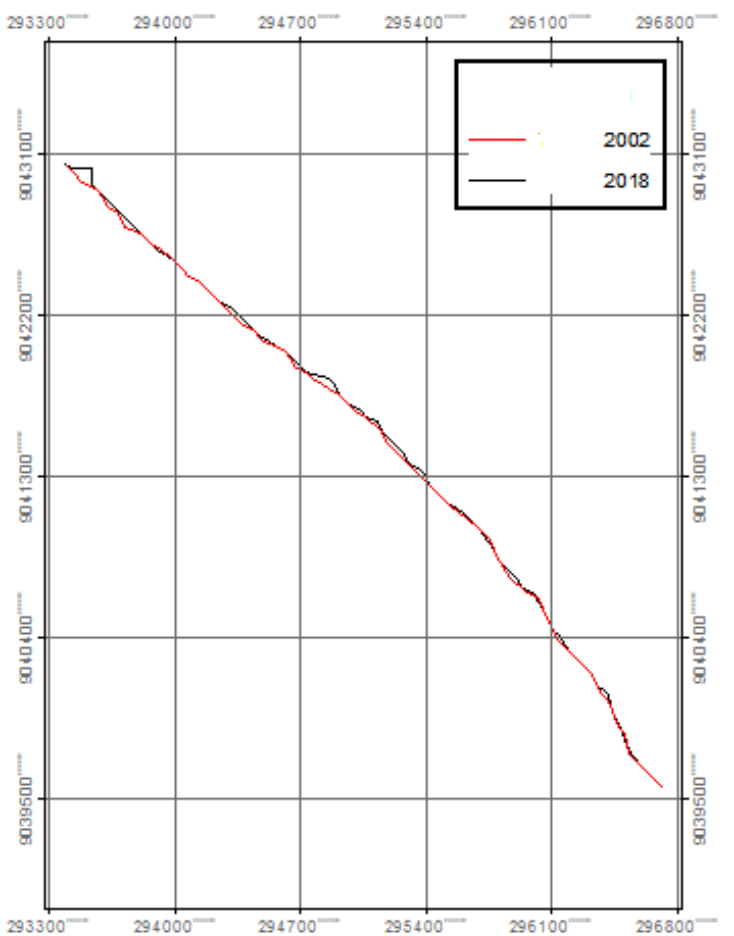

Fig. 14 The coastline results in 2002 and 2018 from the digitization process

\section{Coastline Correction}

The coastline that has been obtained from the digitization results must be corrected first by using the tidal data of the image area under review. Tidal data can be seen in Figure 15. The data obtained from [5] in the form of a slope distribution map on the island of Bali can be seen in Figure 16.

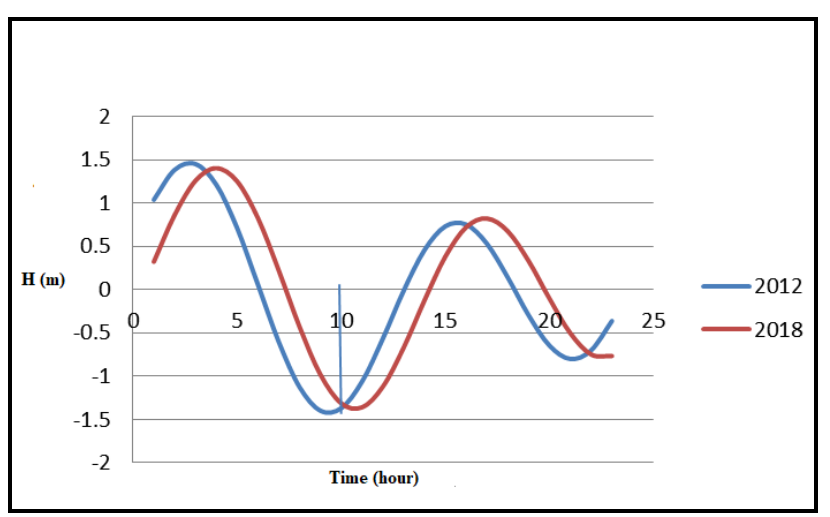

Fig. 15 Tidal pattern charts for 2002 and 2018

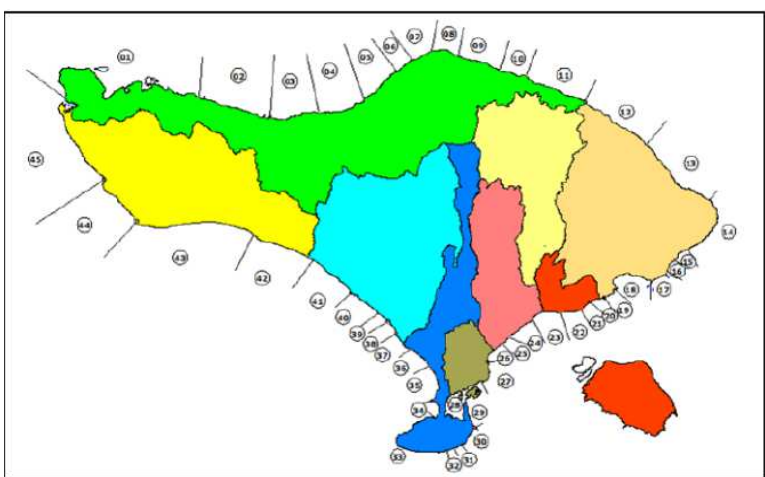

Fig. 16 Map of the Distribution of Slopes on the Island of Bali (Source: BWS-BP, 2015) 
In Figure 16 data, it is explained that the North Kuta subdistrict is on sections 35 and 36, and the slope data covering the section can be seen in Table 1 .

TABLE I

LIST OF HWL VALUES IN THE LOCATION SECTION IN BADUNG REGENCY

\begin{tabular}{cccc}
\hline $\begin{array}{c}\text { Segment } \\
\text { Number }\end{array}$ & $\begin{array}{c}\text { City / } \\
\text { Regency }\end{array}$ & Slope & HWL \\
\hline 29 & Badung & $1: 11$ & 2.60 \\
30 & Badung & $1: 11$ & 2.60 \\
31 & Badung & $1: 1$ & 2.60 \\
32 & Badung & $1: 12$ & 2.60 \\
33 & Badung & $1: 1$ & 2.60 \\
34 & Badung & $1: 19$ & 2.60 \\
35 & Badung & $1: 26$ & 2.60 \\
36 & Badung & $1: 19$ & 2.60 \\
\hline
\end{tabular}

Source: $B W S-B P, 2015$

From Table 3, we obtained slope data in the North Kuta area in section 36 . The coastline correction was performed using the slope data with calculations according to Equation:

$$
Y=(T k-(T k / T b-T x) x \operatorname{Tan} \emptyset)
$$

Where Y: Correction of the coastline in meters; Tk: HWL location in meters; Tb: HWL Benoa in meters; Tx: Tidal wave height in meters; TanØ: Comparison of slopes in the coastal area of North Kuta District.

The results of the correction calculation for the coastal area of North Kuta District can be seen in Table 2. Tidal correction is carried out if the shift due to tides is greater than $1 / 2$ the image resolution with a resolution of 30 meters which is equal to 15 meters. Shifts that occur do not exceed the provisions of 15 meters, then do not do coastline correction due to tides.

TABLE II

COASTLINE CORRECTION IN 2002 AND 2018

\begin{tabular}{|c|c|c|c|c|c|c|c|}
\hline & 气ั๊ & $\stackrel{\Xi}{\Xi}$ & $\underset{\mathrm{E}}{\widehat{\mathrm{E}}}$ & 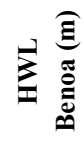 & 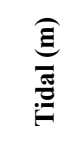 & $\frac{\check{L}}{\hbar}$ & 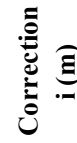 \\
\hline 36 & $28 / 05 / 2002$ & 10 & 1.50 & 2.60 & 1.369 & 19 & 13.49 \\
\hline 36 & $17 / 06 / 2018$ & 10 & 1.50 & 2.60 & 1.300 & 19 & 14.25 \\
\hline
\end{tabular}

\section{J. Analysis of Coastline Change}

After all the stages have been carried out to get to the shoreline in 2002 and 2018, an analysis process was carried out using the DSAS method. DSAS processes data by overlaying 2002 and 2018 coastlines. The observed time interval for coastline changes is 16 years from the data obtained. The distance of the change in coastline can be determined by the length of each transect that is intersected between the coastlines.

The distance between the coastlines that have been overlapped is calculated using a manual transect that is made following the contours of the coastline. Transects made have an interval of 50 meters and a length of 500 meters. The distance between transects is made 50 meters to cover almost all changes that occur, while the length of 500 meters is made to anticipate the coastline that does not cut transects so that the distance calculation between coastlines can be done. The shoreline transect calculation is seen in Figure 17.

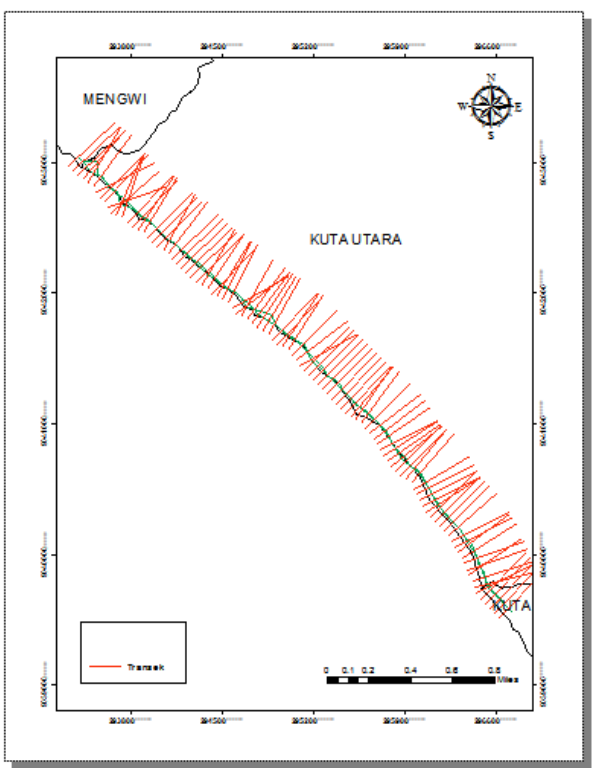

Fig. 17 Transect calculation of the distance between the North Kuta coastline

The coastline resulting in the Landsat image extraction changed from 2002 to 2018 . Researchers visually made the identification of changes, with the shoreline of each year being overlapped. Identification of shoreline changes is carried out along the Batu Mejan beach, which is in transect 1 to transect 22. Identification of changes in the coastline of Batu Mejan can be seen in Figure 18.

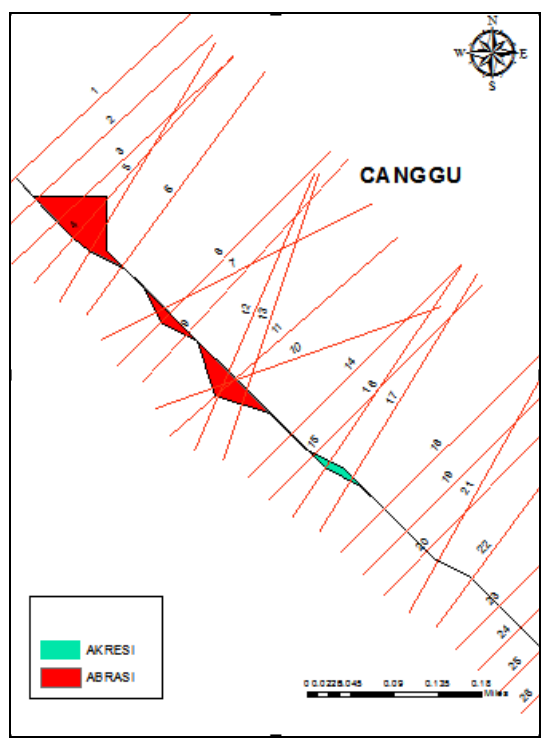

Fig. 18 Overlapping the Batu Mejan coastline

The changes in coastline's pattern changes in Batu Mejan Beach experiences dominant erosion. Erosion that occurs on average is quite high. The highest erosion occurred on the $4^{\text {th }}$ transect with 82.84 meters. Accretion only occurs in transects 15, 16 and 17, with the highest accretion on transect 16 of 13.52 meters. The average change in coastline at Pantai Batu Mejan is 17.34 meters. Changes in the coastline at Batu Mejan Beach are shown by the graph in Figure 19. The rate of change in the coastline at Pantai Batu Mejan is dominated by erosion. Rate of change in the coastline at Batu Mejan Beach showed abrasion of 0.11-5.14 
$\mathrm{m} /$ year and accretion of $0.29-0.84 \mathrm{~m} /$ year. The highest erosion rate occurred in the $4^{\text {th }}$ transect of $5.14 \mathrm{~m} / \mathrm{yr}$, and the average rate of change in the coastline at Batu Mejan Beach was $1.08 \mathrm{~m} / \mathrm{yr}$.

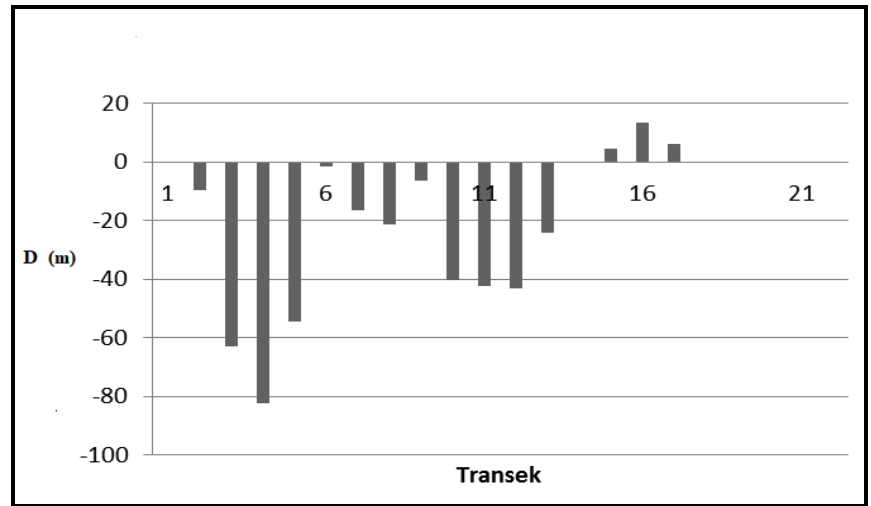

Fig. 19 A graph of the coastline changes of each transect in Batu Mejan Beach

\section{K. Validation with Google Earth}

The coastline vector resulting from Landsat image delineation must be validated with valid data to determine the method's accuracy. The data used for validation can be from various sources, such as from data taken directly in the field or other data from other sources such as Google Earth data. This study uses visual validation by overlaying the coastline that was created with maps obtained from Google Earth. The overlay result matches the coastline that has been created with a map from Google Earth [19] can be seen in Figure 20 and Figure 21.
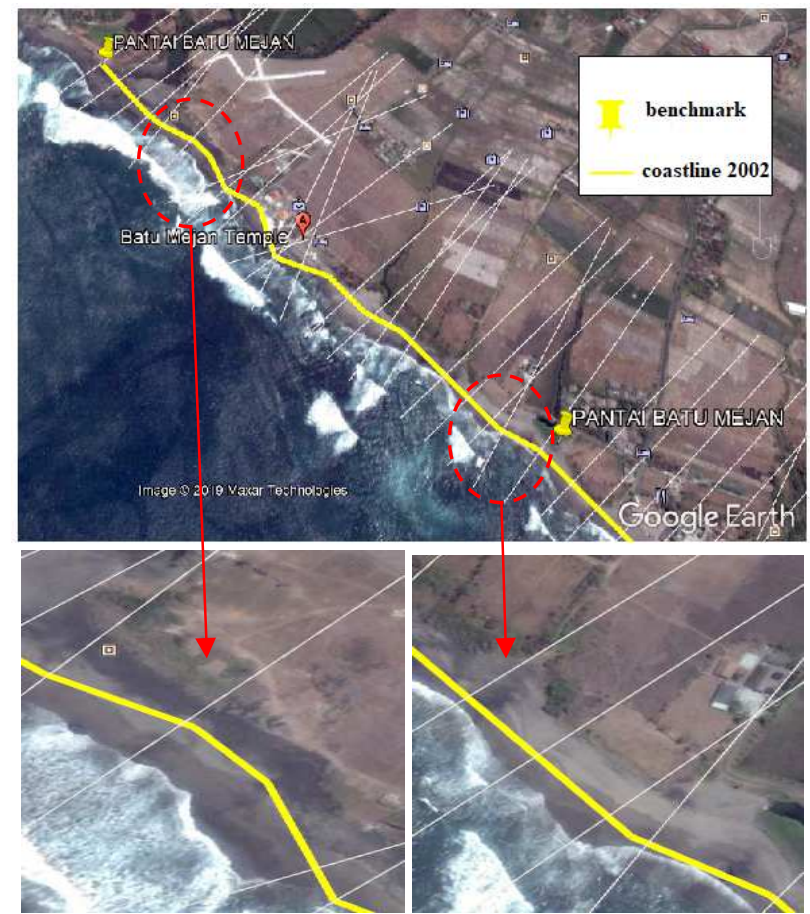

Fig. 20 Results of a coastline overlay with Google Earth in 2002

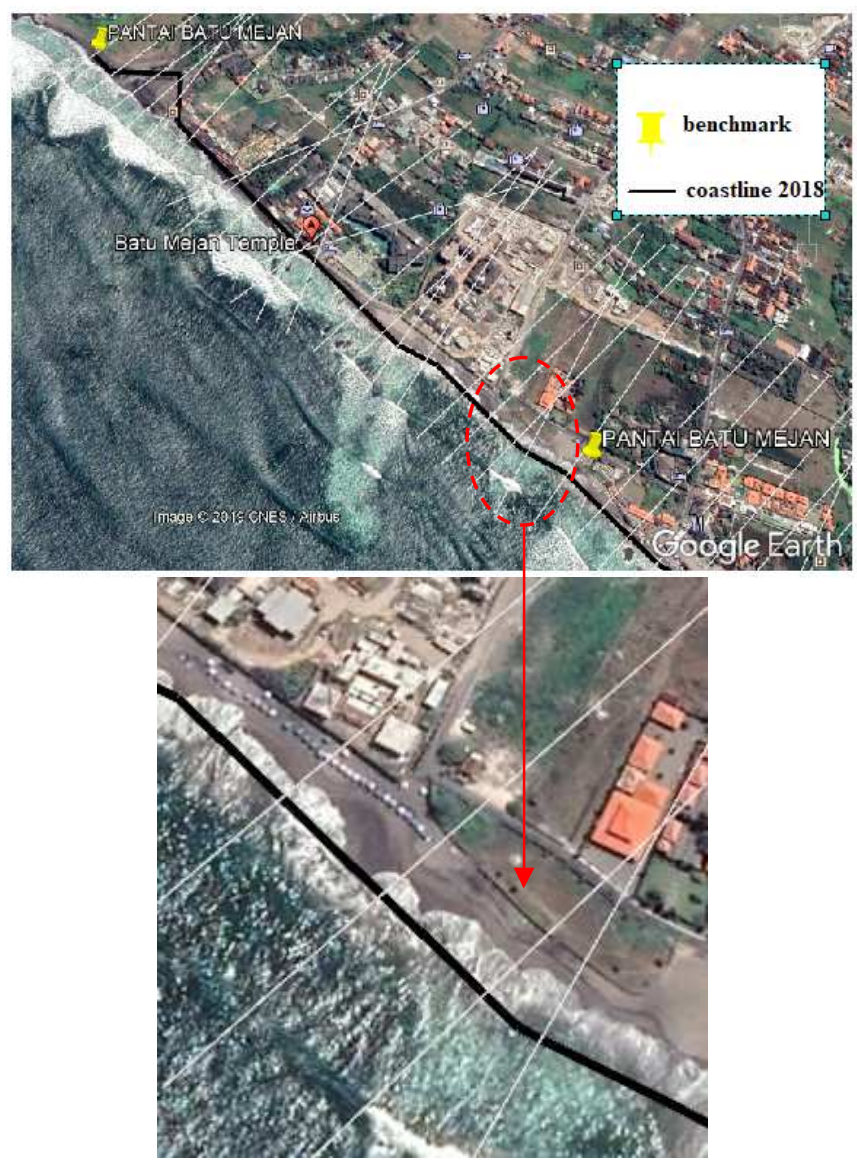

Fig. 21 Results of a coastline overlay with Google Earth in 2018

\section{CONCLUSIONS}

Coastal changes that occur at Batu Mejan Beach can be analyzed using Landsat Satellite Imagery Data. The shoreline extraction at Baju Mejan Beach is obtained by analyzing remote sensing images, including geometric corrections, radiometric corrections, image cuts, composite Landsat bands, image thresholding, band ratios, threshold and band ratio combinations, and classification and digitization of shoreline vectors.

The rate of change is calculated using images that are processed using the DSAS calculation method. The coastline at Batu Mejan Beach has been identified as changing at different rates for each segment. The pattern of shoreline change in the area, which includes Batu Mejan Beach, shows the rate of change in the shoreline, abrasion of 0.11-5.14 $\mathrm{m}$ /year, and accretion of 0.29-0.84 m/year.

Analyzed with other available images as a comparison to the results of Landsat resolution image processing is suggested. In order to make use of remote sensing imagery by the relevant agencies or institutions in monitoring changes in coastline, it is important to support overall coastal management efforts.

\section{ACKNOWLEDGMENT}

We are grateful to the Institute for Research and Community Service of Udayana University (LPPM Unud) for funding this research. The results of this study are collaboration research between Udayana University and Yamaguchi University. 


\section{REFERENCES}

[1] E. J. Powell, M. C. Tyrrell, A. Milliken, J. M. Tirpak, and M. D. Staudinger, "A review of coastal management approaches to support the integration of ecological and human community planning for climate change," J. Coast. Conserv., vol. 23, no. 1, pp. 1-18, 2019, doi: 10.1007/s11852-018-0632-y.

[2] P. B. Zamora, M. B. Cardenas, R. Lloren, and F. P. Siringan, "Seawater-groundwater mixing in and fluxes from coastal sediment overlying discrete fresh seepage zones: A modeling study," $J$. Geophys. Res. Ocean., vol. 122, no. 8, pp. 6565-6582, 2017, doi: 10.1002/2017JC012769.

[3] C. Jordan, J. Visscher, N. V. Dung, H. Apel, and T. Schlurmann, "Impacts of human activity and global changes on future morphodynamics within the tien river, vietnamese mekong delta," Water (Switzerland), vol. 12, no. 8, 2020, doi: 10.3390/w12082204.

[4] Badung Regency Local Goverment, "Peraturan Daerah Kabupaten Badung No. 26 Tahun 2013 tentang Rencana Tata Ruang Wilayah Kabupaten Badung Tahun 2013 - 2033,” 2013.

[5] BWS-BP, "Studi Updating Abrasi Pantai Provinsi Bali," Balai Wil. Sungai Bali-Penida, 2015.

[6] P. Ni Nyoman, A. Diputra I Gede, J. Made W, and M. INK, "Coastal protection work for Batu Mejan Beach, Bali," MATEC Web Conf., vol. 276, p. 04019, 2019, doi: 10.1051/matecconf/201927604019.

[7] P. N. Nyoman, S. Ketut, and A. C. Saputra, "Revitalizing the Batu Mejan Beach with Geotextile Breakwater," IOP Conf. Ser. Earth Environ. Sci., vol. 248, no. 1, 2019, doi: 10.1088/17551315/248/1/012080.

[8] M. Yasir et al., "Automatic Coastline Extraction and Changes Analysis Using Remote Sensing and GIS Technology," IEEE Access, vol. $8, \quad$ pp. 180156-180170, 2020, doi: 10.1109/ACCESS.2020.3027881.

[9] M. Bouchahma, W. Barhoumi, W. Yan, and H. Al Wardi, "Opticalflow-based approach for the detection of shoreline changes using remote sensing data," Proc. IEEE/ACS Int. Conf. Comput. Syst. Appl. AICCSA, vol. 2017-October, pp. 184-189, 2018, doi: 10.1109/AICCSA.2017.173.

[10] X. K. Zhang, X. Zhang, Q. Q. Lan, and M. H. Ali Baig, “Automated detection of coastline using Landsat TM based on water index and edge detection methods," Proc. 2nd Int. Work. Earth Obs. Remote Sens. Appl. EORSA 2012, pp. 153-156, 2012, doi: 10.1109/EORSA.2012.6261155.

[11] E. A. Himmelstoss, R. E. Henderson, M. G. Kratzmann, and A. S. Farris, "Digital Shoreline Analysis System (DSAS) version 5.0 user guide," Reston, VA, 2018. doi: 10.3133/ofr20181179.

[12] R. M. Abou and R. R. Ali, "The Egyptian Journal of Remote Sensing and Space Sciences Applying DSAS tool to detect coastal changes along Nile Delta , Egypt,” Egypt. J. Remote Sens. Sp. Sci., no. xxxx, 2020, doi: 10.1016/j.ejrs.2020.11.002.

[13] R. Bera and R. Maiti, "Quantitative analysis of erosion and accretion (1975-2017) using DSAS - A study on Indian Sundarbans," Reg. Stud. Mar. Sci., vol. 28, p. 100583, 2019, doi: 10.1016/j.rsma.2019.100583.

[14] M. R. Muskananfola, Supriharyono, and S. Febrianto, "Spatiotemporal analysis of shoreline change along the coast of Sayung Demak, Indonesia using Digital Shoreline Analysis System," Reg. Stud. Mar. Sci., vol. 34, p. 101060, 2020, doi: 10.1016/j.rsma.2020.101060.

[15] Nithu Raj, B. Gurugnanam, V. Sudhakar, and P. Glitson Francis, "Estuarine shoreline change analysis along The Ennore river mouth, south east coast of India, using digital shoreline analysis system," Geod. Geodyn., vol. 10, no. 3, pp. 205-212, 2019, doi: 10.1016/j.geog.2019.04.002.

[16] W. Cao, Y. Zhou, R. Li, and X. Li, "Mapping changes in coastlines and tidal flats in developing islands using the full time series of Landsat images," Remote Sens. Environ., vol. 239, no. December 2019, p. 111665, 2020, doi: 10.1016/j.rse.2020.111665.

[17] C. Chen, J. Fu, S. Zhang, and X. Zhao, "Coastline information extraction based on the tasseled cap transformation of Landsat-8 OLI images," Estuar. Coast. Shelf Sci., vol. 217, pp. 281-291, 2019, doi: 10.1016/j.ecss.2018.10.021.

[18] W. Nijland, L. Reshitnyk, and E. Rubidge, "Satellite remote sensing of canopy-forming kelp on a complex coastline: A novel procedure using the Landsat image archive," Remote Sens. Environ., vol. 220, no. October 2018, pp. 41-50, 2019, doi: 10.1016/j.rse.2018.10.032.

[19] Google Earth, "Image of Batu Mejan,” Jun. 2019. 